\title{
Degumming, Perlakuan Alkali, dan Karakterisasi Serat Pandan Berduri (Pandanus tectorius)
}

(Degumming, Alkali Treatment, and Characterization of Pandanus tectorius Fiber)

\author{
Sudarisman ${ }^{a}$, Nanda Satria Atmaja ${ }^{b}$, Muhammad Budi Nur Rahman ${ }^{c}$, Kunto Purbono ${ }^{d}$ \\ ${ }^{a, b, c}$ Program Studi S1 Teknik Mesin, Universitas Muhammadiyah Yogyakarta \\ Jalan Brawijaya, Tamantirto, Bantul 55183 \\ +62 274387656 \\ e-mail: sudarisman@umy.ac.id, nanda_satria48@yahoo.com, budinurrahman@umy.ac.id \\ dProgram Studi Teknik Mesin, Politeknik Negeri Semarang \\ Jalan Prof. Sudarto, S.H., Tembalang, Semarang 50275 \\ +62 0247473417 Ext. 213 \\ e-mail: kunto.purbono@polines.ac.id
}

\begin{abstract}
Abstrak
Penelitian ini bertujuan untuk mengetahui pengaruh parameter degumming terhadap sifat tarik serat pandan berduri (Pandanus Tectorius). Daun pandan berduri lokal direndam dalam waterbath pada suhu $95^{\circ} \mathrm{C}$ selama $1,2,3$, atau 4 jam, kemudian dipres untuk diambil seratnya. Serat kemudian direndam dalam larutan $\mathrm{NaOH}$ dengan kadar 2,5 wt\% atau 5 wt\% selama 2 jam. Selanjutnya, proses dilanjutkan dengan menetralisasi dengan direndam dalam air bersih selama $8 \times 6 \mathrm{jam}$ dan dikeringkan pada suhu kamar. Uji tarik dilakukan untuk mengetahui kuat tarik, regangan dan modulus elastisitas serat. Pemisahan serat dari daun pandan berduri berhasil dilakukan. Hasil uji tarik menunjukkan bahwa serat yang dialkalisasi dengan $\mathrm{NaOH} 5$ wt\% diperoleh kuat tarik yang lebih rendah dibandingkan dengan yang konsentrasi $\mathrm{NaOH}-n y a$ 2,5 wt\%. Pada kadar $\mathrm{NaOH} 2,5$ wt\%, naiknya lama waktu perendaman sampai dengan 3 jam juga akan menaikkan kuat tarik serat. Kuat tarik, regangan patah dan modulus elastisitas tertinggi diperoleh dengan perlakuan alkali dengan kadar $\mathrm{NaOH} 2,5$ wt\%. Kuat tarik, regangan patah dan modulus elastisitas tertinggi, berturut-turut 203,02 MPa, 3,733\% dan 11,938 GPa, diperoleh dari lama waktu perendaman 3 jam.
\end{abstract}

Kata kunci: Degumming, Perlakukan Alkali, Serat Pandan Berduri, Sifat Tarik

\begin{abstract}
The objective of this research is to determine the effect of degumming parameters on tensile properties of the resulted local (Pandanus Tectorius) fiber. Prickly pandanus leaves were soaked in a waterbath containing plain water at $95^{\circ} \mathrm{C}$ for either 1, 2, 3, or 4 hours, then pressed to yield their fibers. The fibers were then soaked in a solution containing either $2,5 \mathrm{wt} \%$ or $5 \mathrm{wt} \%$ of $\mathrm{NaOH}$ for 2 hours. Next, the fibers were neutralized by soaking them in plain water for $8 \times 6$ hours, and slowly dried at room temperature. Tensile test was carried out to obtain the tensile strength, strain-to-failure and modulus of the fibers. Fiber separation from Pandanus Tectorius leaves has successfully been carried out. It was found out that pretreatment using 2,5 wt\% $\mathrm{NaOH}$ content solution produced higher tensile strength, strain-to-failure and elastic modulus in comparison with those using $5 \mathrm{wt} \% \mathrm{NaOH}$ content solution. Tensile properties increases with the increase of soaking time up to 3 hours. The highest tensile strength, strain-tofailure and modulus, 203.02 $\mathrm{MPa}, 3.733 \%$ and $11.938 \mathrm{GPa}$, respectively, were obtained at 3 hours of soaking time.
\end{abstract}

Keywords: Degumming, Alkali Treatment, Pandanus Tectorius Fiber, Tensile Properties 


\section{Pendahuluan}

Karena kelebihannya dibandingkan dengan material konvensional, antara lain ringan, dapat dirancang untuk memperoleh kekuatan dan kekakuan optimal, ketahanan leleh yang tinggi, tahan korosi, dengan perancangan yang cermat dihasilkan produk dengan biaya perakitan yang rendah karena jumlah komponen dan proses penyambungan yang lebih sedikit [1], material komposit semakin banyak digunakan [2] termasuk dalam dunia industri manufaktur. Pemakaian serat sintetis yang memiliki kekuatan tinggi sebagai penguat material komposit memiliki dampak samping yakni polusi dari proses produksinya dan pasca-pakai produknya memerlukan waktu yang lebih lama untuk terurai secara alamiah sehingga menimbulkan masalah berupa sampah dan pencemaran lingkungan terutama yang berkaitan dengan sampah plastik [3].

Serat sintetis merupakan serat yang dibuat dari bahan anorganik dengan komposisi kimia tertentu. Serat sintetis yang banyak digunakan antara lain: serat gelas, serat karbon, dan nilon. Karena pertimbangan pelestarian lingkungan, pada beberapa dekade terakhir ini serat alami, baik yang berasal dari tumbuhan maupun hewan, mulai banyak digunakan untuk substitusi serat sintetis, karena lebih ramah lingkungan dan dapat diperbaharui. Serat alami adalah serat yang berasal dari alam biasanya berupa serat organik. Serat alam yang sudah diteliti diantaranya adalah: ramie, flax, henep, jute, sisal, kapas, sabut kelapa, wool dan sutera [4]. Kelemahan serat ini diantaranya ukuran serat yang tidak seragam, dan sifat mekanisnya yang bervariasi [4] tergantung pada faktor usia dan musim saat dipanen, lokasi dan iklim tempat tumbuh atau berkembangnya sumber serat tersebut. Perkembangan serat alam sebagai bahan material komposit ini sangat dimaklumi mengingat dari segi ketersediaan bahan baku serat alam di Indonesia yang sangat melimpah [5].

Serat pandan berduri (Pandanus Tectorius) merupakan salah satu material serat alami (natural fibre) yang berpotensi dimanfaatkan dalam pembuatan komposit. Serat pandan berduri yang dikombinasikan dengan epoksi sebagai matrik, akan menghasilkan komposit alternatif yang bermanfaat untuk dunia industri. Serat ini dipilih karena banyak tesebar di Indonesia khususnya daerah dataran rendah sehingga mudah didapat. Di Indonesia, pandan berduri dapat ditemukan di sepanjang garis pantai.

Walaupun beberapa penelitian tentang pemanfaatan serat pandan berduri sebagai penguat bahan komposit namun masih belum banyak diteliti dan dilaporkan tentang pengaruh parameter proses degumming terhadap kuat tarik serat pandan berduri. Penelitian ini bertujuan untuk mengetahui pengaruh lama waktu degumming dan kadar $\mathrm{NaOH}$ dalam proses perlakuan permukaan terhadap sifat-sifat tarik serat pandan berduri yang diperoleh sehingga optimasi pemanfaatan potensi karakteristik mekanisnya dapat dioptimalkan.

\section{Metode Penelitian}

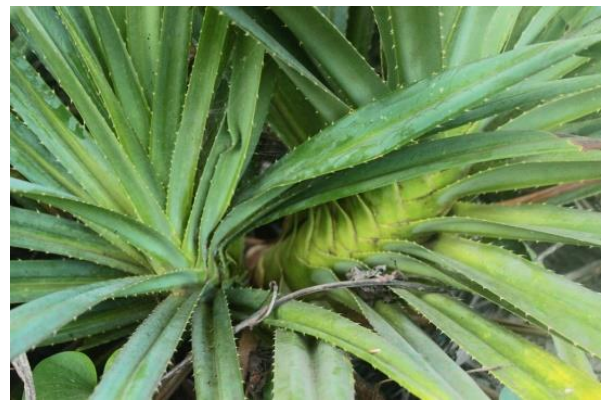

(a)

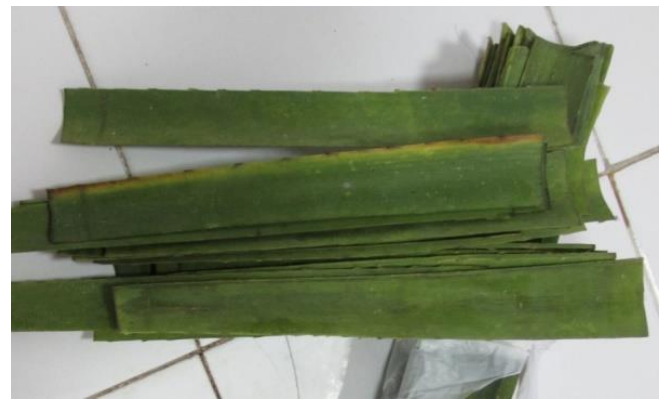

(b)

Gambar 2.1. (a) Pohon pandan berduri, (b) Daun pandan yang dipotong sepanjang $20 \mathrm{~cm}$

Variabel bebas dalam penelitian ini terdiri dari waktu degumming (1, 2, 3 atau 4 jam), dan kadar alkali dalam perendaman perlakuan pendahuluan serat (2,5 atau $5 \mathrm{wt} \%$ ). Sementara itu, suhu degumming dibuat tetap $95^{\circ} \mathrm{C}$, demikian juga waktu perendaman perlakuan pendahuluan dibuat tetap 2 jam. 


\subsection{Persiapan Serat}

Daun pandan berduri diperoleh dari daerah pantai Parangtritis, Bantul, dengan mengambil daun yang ketiga dan keempat terbawah (Gambar 2.1(a)), sehingga daun tersebut telah cukup tua. Daun tersebut kemudian dipotong sepanjang sekitar $20 \mathrm{~cm}$ (Gambar 2.1(b)) sesuai dengan panjang waterbath yang akan digunakan. Sebelum direndam dalam waterbath, serat tersebut dicuci, dipres dan dilayukan. Setelah layu, serat tersebut dimasukkan ke dalam waterbath yang berisi air pada suhu konstan $95^{\circ} \mathrm{C}$, selama 1, 2, 3, atau 4 jam. Serat tersebut kemudian diangkat, ditiriskan dan dipres kembali untuk memisahkan serat dari gum-nya. Serat yang diperoleh kemudian dicuci dan dianginanginkan sehingga kering (Gambar 2.2). Selanjutnya, serat direndam selama 2 jam dalam larutan berkadar 2,5 atau 5 wt\% alkali untuk menurunkan kadar lemak dan pektin pada serat. Tahap berikutnya adalah netralisasi, yakni dengan merendam serat tersebut dalam air tawar selama $8 \times 6$ jam, setiap 6 jam serat dibilas dan air rendamannya diganti. Tahap terakhir, serat kemudian diangin-anginkan agar kering perlahan sehingga terjadi pengeringan yang seimbang antara bagian dalam dengan bagian luar dan retak halus permukaan serat dapat dihindari.

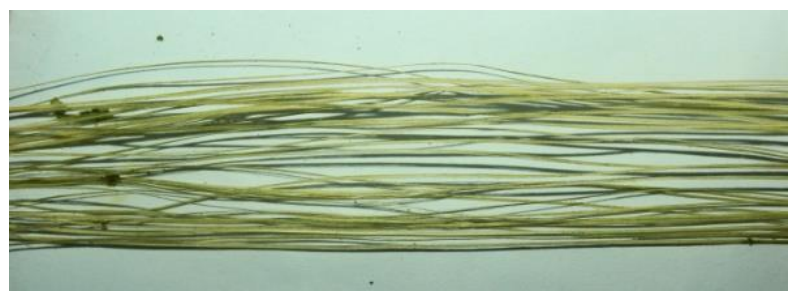

Gambar 2.2. Serat yang diperoleh dari proses deguming

\subsection{Pembuatan Spesimen}

Spesimen uji dibuat dengan mengacu pada Fidelis dkk. [6] dengan modifikasi panjang holder dan panjang ukur seratnya. Panjang holde dibuat $110 \mathrm{~mm}$ dan panjang ukur serat dibuat $10 \mathrm{~mm}$. Setelah dilakukan perlakuan pendahuluan, serat kemudian dipasang pada holder yang terbuat dari lembaran karton dengan tebal 0,8 mm dengan ukuran panjang 110 $\mathrm{mm}$ dan lebar $80 \mathrm{~mm}$. Karton tersebut dilipat pada lebarnya secara simetris, kemudian tepat di tengah nya dibuat lubang berukuran 20x10 mm2 seperti terlihat pada Gambar 2.3(a).

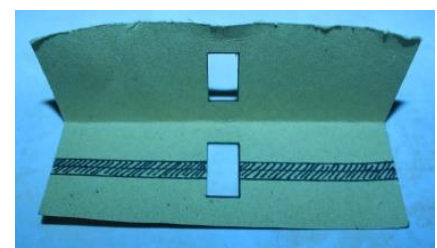

(a)

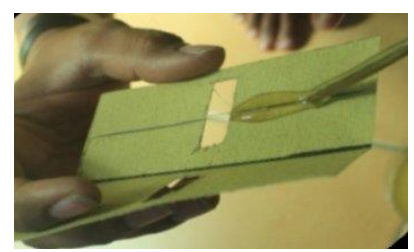

(b)

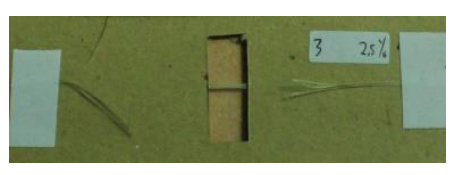

(c)

Gambar 2.3. Spesimen: (a) Holder, (b) Pemasangan serat, (c) Spesimen siap uji

Serat ditarik sehingga lurus namun tidak sampai mengalami beban awal, diletakkan pada holder sesuai dengan posisinya, dilipat ke belakang dan ditahan dengan pita perekat (cellotape). Serat kemudian direkatkan pada holder menggunakan epoksi sebagai perelatnya, sekaligus sebagai perekat antara dua sisi lipatan holder (Gambar 2.3(b)). Selama menunggu perekatnya kering, spesimen tersebut ditindih dengan beban mati, dan setelah kering diperoleh spesimen siap uji seperti terlihat pada Gambar 2.3(c). Pada Gambar 2.3(c) juga terlihat sisa panjang serat yang terlipat ke belakang dan ditahan dengan pita perekat. 


\subsection{Pengujian Tarik}

Pengujian tarik dilakukan di Laboratorium Material Teknik, Jurusan Teknik Mesin, Universitas Sebelas Maret, Surakarta dengan menggunakan mesin COM SERVO berkapasitas 50 kgf. Tahapan pengujian ditunjukkan pada Gambar 2.4.

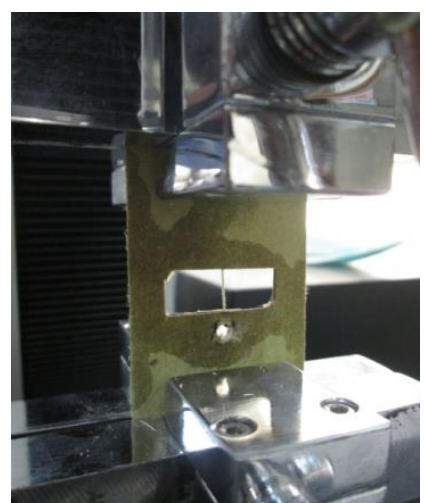

(a)

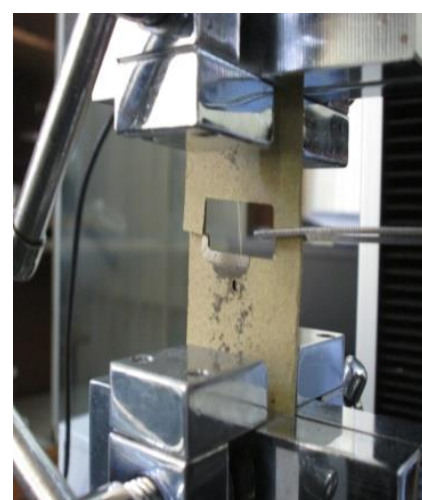

(b)

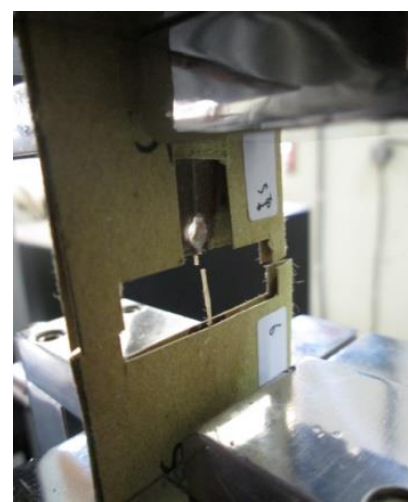

(c)

Gambar 2.4. Pengujian: (a) Pemasangan spesimen, (b) Pemotongan holder, (c) Serat setelah putus

Spesimen dipasang pada penjepit pada posisi serat benar-benar lurus vertikal (Gambar 2.4(a)), kemudian holder dipotong sehingga memisahkan bagian atas dengan bagian bawahnya (Gambar 2.4(b)). Setelah holder terpotong, maka penarikan serat mulai dilakukan sampai dengan serat tersebut putus (Gambar 2.4(c)).

\subsection{Penghitungan Kuat Tarik, Regangan Patah dan Modulus Elastisitas Serat}

Dari hasil pengujian tarik kemudian dihitung kuat tarik, regangan patah dan modulus elastisitas serat menggunakan persamaan-persamaan (1) sampai dengan (3) [7].

$$
\begin{aligned}
& \sigma=\frac{F_{\max }}{A}(\mathrm{MPa}) \\
& \varepsilon=\frac{\delta}{l_{\mathrm{o}}}(\mathrm{MPa}) \\
& E=\frac{\Delta F}{\Delta \delta} \cdot \frac{l_{\mathrm{o}}}{A} \quad(\mathrm{MPa})
\end{aligned}
$$

Keterangan:

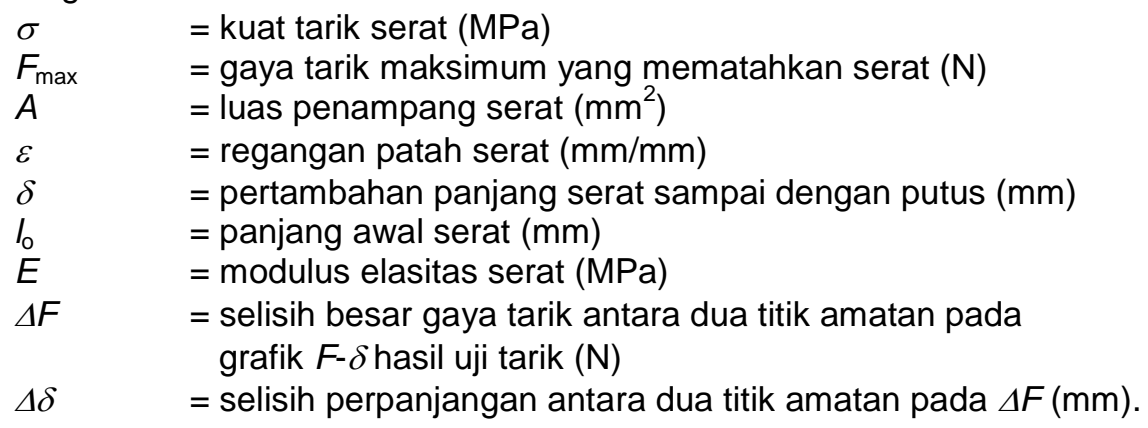

Besar gaya tarik dan perpanjangan serat diperoleh dari luas penampang serat diperoleh dengan menghitung luas fotomikro penampang serat dengan prosedur seperti dijelaskan pada sub-bagian 2.5. $\Delta F$ dan $\Delta \delta$ diukur pada pada bagian awal hubungan proporsional antara $F$ - $\delta$ grafik hasil pengujian tarik serat. 


\subsection{Pengukuran Luas Penampang Serat}

Sejumlah serat dipilih secara acak sebagai sampel untuk diambil foto mikro penampangnya. Luas penampang serat diukur dengan mengukur luasan foto mikro penampang serat dengan menggunakan perangkat lunak terbuka imageJ [8]. Foto mikro diperoleh dengan menggunakan mikroskop optik Zeiss yang dilengkapi dengan kamera digital Axiolab pol $(0,5)$ beresolusi maksimum 5 megapixel. Pengukuran diperoleh dalam pixel persegi yang kemudian dikonversi berdasar pada mistar digital dari kamera digital tersebut.

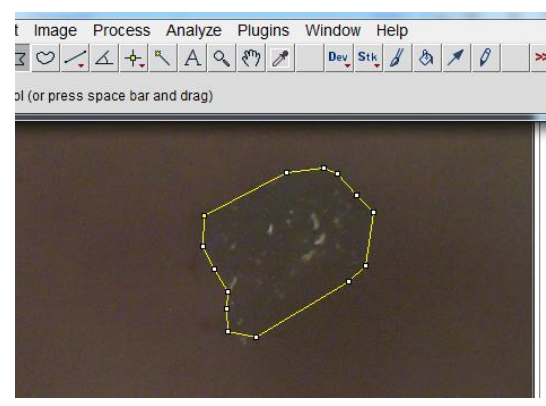

(a)

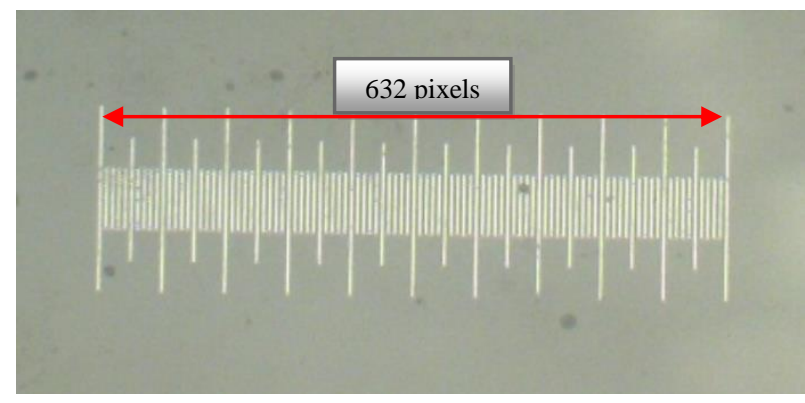

(b)

Gambar 2.5 Pengukuran luas penampang serat: (a) Fotomikro penampang serat sampel, (b) mistar kalibrator

\subsection{Pengamatan Moda Patahan}

Moda patahan serat dievaluasi dengan mengamati secara cermat fotomikro dan SEM dari sampel serat yang telah diuji hingga putus. Foto SEM diperoleh dengan menggunakan scanning electron microscope (SEM, FEI Inspect S50) di Laboratorium Sentral FMIPA, Universitas Negeri Malang, sedangkan fotomikro diperoleh dengan menggunakan mikroskop yang digunakan untuk pengukuran luas penampang serat.

\section{Hasil Pembahasan}

3.1 Hubungan Gaya Tarik-Perpanjangan ( $F-\delta$ )

Contoh grafik hubungan gaya tarik dengan perpanjangan pada uji tarik ditunjukkan pada Gambar 3.1. Grafik dapat dibagi menjadi tiga bagian. Daerah AB merupakan daerah terjadinya pelurusan serabut serat yang ditandai dengan hubungan yang tidak berpola antara $F$ dengan $\delta$, sampai dengan dicapainya kelurusan sebagian besar serabut serat. Daerah $\mathrm{BC}$ merupakan daerah terjadinya peregangan serat yang ditandai dengan hubungan linier $F-\delta$, sedangkan daerah $C D$ merupakan daerah laju peregangan yang tinggi dengan penurunan besar gaya tarik yang menandai terjadinya proses putusnya serat.

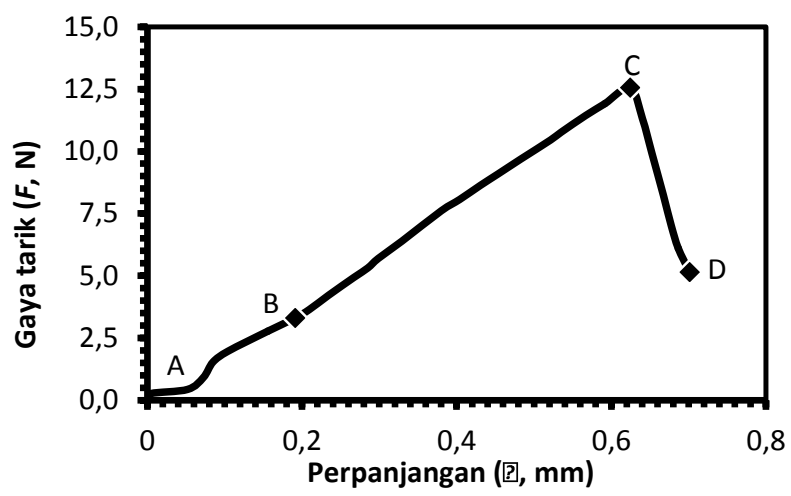

Gambar 3.1 Hubungan gaya tarik dengan perpanjangan 
3.2 Kuat Tarik

Pada Gambar 3.2 terlihat bahwa kuat tarik serat mencapai optimal tergantung pada kadar alkali pada larutan perendam. Semakin tinggi kadar alkali maka pendek waktu yang diperlukan untuk memperoleh kuat tarik optimal seratnya. Pada kadar alkali 2,5 wt\%, kuat tarik optimal dicapai pada waktu perendaman 3 jam, sedangkan pada kadar alkali $5 \mathrm{wt} \%$ hanya diperlukan waktu perendaman 2 jam.

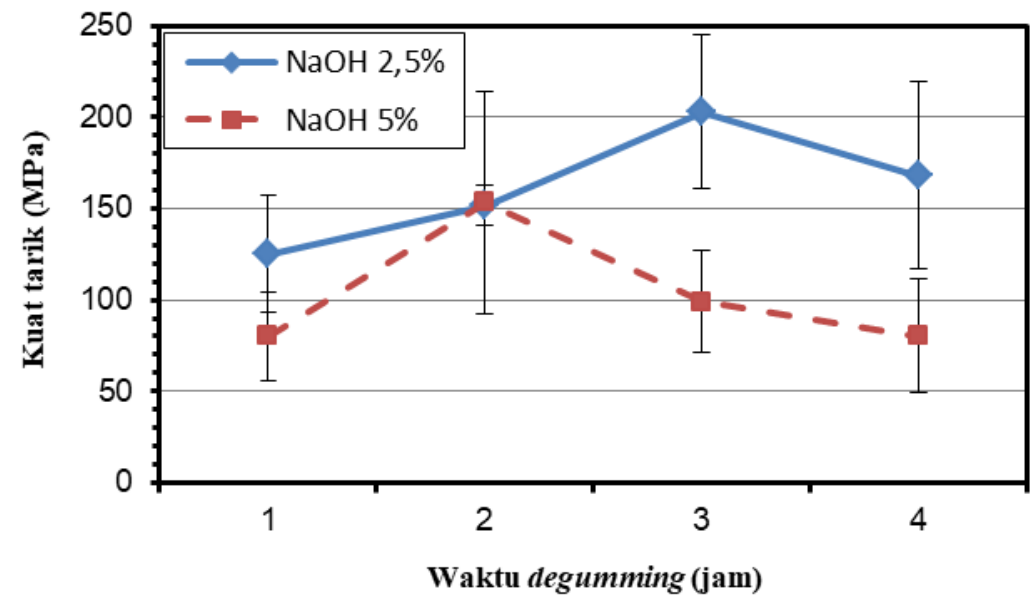

Gambar 3.2. Hubungan lama perendaman dengan kuat tarik serat

Kuat tarik optimum serat dari perlakuan dengan kadar alkali 2,5 wt\% diperoleh lebih tinggi dibandingkan dengan yang diperoleh dari perlakuan dengan kadar alkali $5 \mathrm{wt} \%$. Pada kadar alkali 2,5 wt\% diperoleh kuat tarik tertinggi 203,02 MPa dengan waktu perendaman 3 jam, sedangkan pada kadar alkali 5 wt\% diperoleh kekuatan tarik tertinggi 153,43 MPa pada waktu perendaman 2 jam. Kuat tarik tersebut setara dengan kuat tarik serat sabut kelapa sebesar $175(\mathrm{MPa})$ [9]. Perlakuan alkali dapat melarutkan sebagian lignin dan menguraikan bendel fiber menjadi fiber individual serta meningkatkan kadar hidroksil pada permukaan serat [10]. Namun demikian, kadar alkali yang terlalu tinggi dan/atau waktu perendaman yang terlalu lama mungkin dapat mencederai serat dan menurun keutuhan struktur serat tersebut, sehingga menurunkan kuat tariknya.

\subsection{Regangan Patah}

Sebagaimana kuat tarik serat, regangan patah serat juga menunjukkan pola yang sama. Regangan patah tergantung pada kadar alkali dan lama waktu perendaman, pada kadar alkali 2,5 wt\% diperoleh regangan patah lebih tingi dibandingkan dengan perendaman pada kadar alkali $5 \mathrm{wt} \%$.

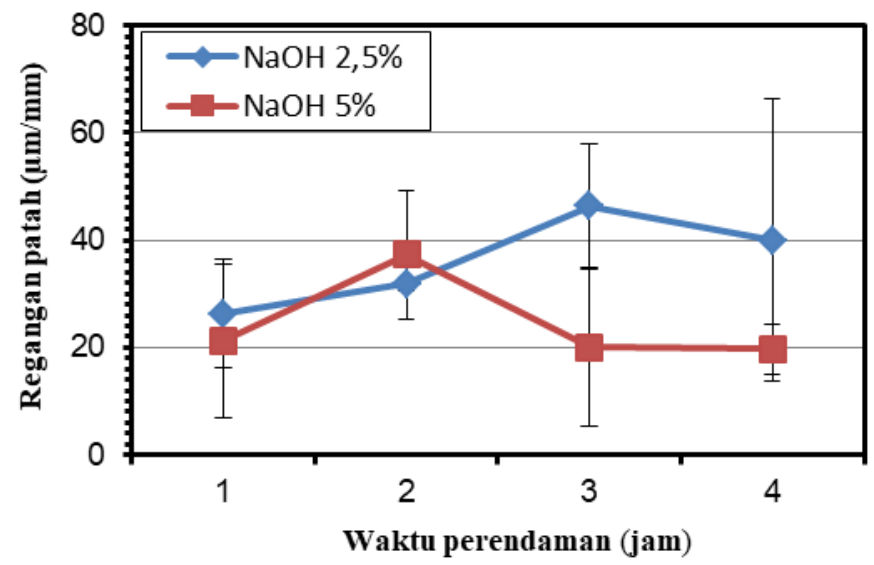

Gambar 3.3. Hubungan lama perendaman dengan regangan parah serat 
Ragangan patah optimum pada perendaman dengan kadar alkali 2,5 wt\% diperoleh pada waktu perendaman 3 jam yakni sebesar $46,29 \mu \mathrm{m} / \mathrm{mm}$ atau $4,629 \%$, sedangkan pada kadar alkali $5 \mathrm{wt} \%$ diperoleh 37,33 $\mu \mathrm{m} / \mathrm{mm}$ atau 3,733\% dengan waktu perendaman 2 jam. Regangan patah ini setara dengan regangan patah serat kenaf $(4,8 \%)$ dan serat henep $(3,05 \%)[11]$.

\subsection{Modulus Elastitas}

Pada kadar alkali 2,5 wt\%, modulus elastisitas meningkat seiring dengan semakin lamanya waktu perendaman sampai dengan 3 jam, sedangkan pada kadar alkali 5 wt $\%$ modulus elastisitas cenderung sedikit menurun dengan semakin lamanya waktu perendaman, seperti terlihat pada Gambar 3.4. Pada kadar alkali 2,5 wt\%, modulus tertinggi diperoleh pada lama waktu perendaman 3 jam, yakni 11,938 GPa. Sedangkan pada kadar alkali $5 \mathrm{wt} \%$ diperoleh modulus tertinggi pada lama waktu perendaman 1 jam yakni 10,369 GPa. Pada perendaman dengan kadar alkali 2,5 wt\% dengan lama waktu perendaman 4 jam diperoleh modulus elastisitas terendah $(7,477 \mathrm{GPa})$, yang mungkin disebabkan larutnya sebagian lignin yang berfungsi sebagai pengikat sehingga terurainya bendel seratnya [10] dan memperbesar laju peregangannya.

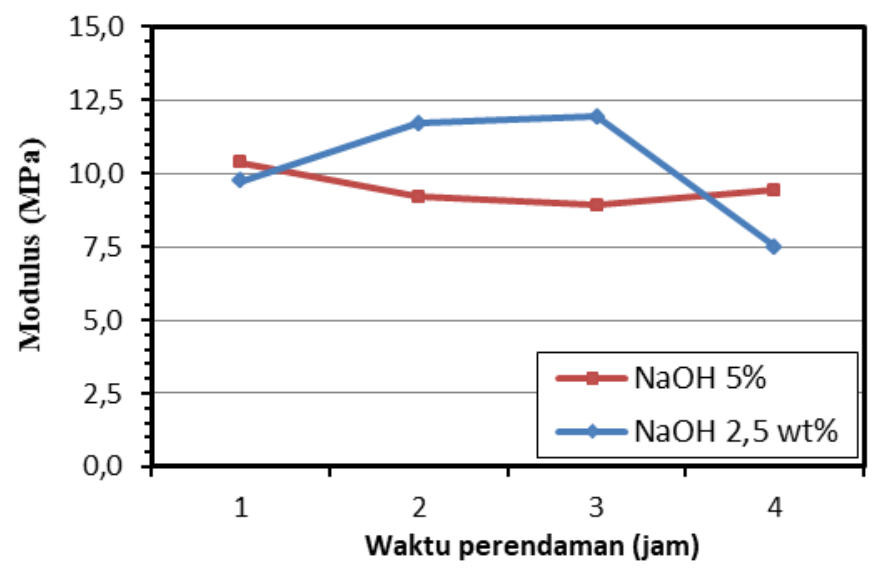

Gambar 3.4. Hubungan lama perendaman dengan modulus elastisitas serat

\section{Kesimpulan}

Proses pemisahan serat dari daun pandan berduri telah berhasil dilakukan dan serat yang diperoleh telah diuji sifat tariknya, dan diperoleh bahwa:

1. Sifat tarik dipengaruhi oleh kadar $\mathrm{NaOH}$ pada perlakuan pendahuluan dan lama waktu perendaman pada perlakuan tersebut.

2. Kuat tarik, regangan patah dan modulus elastisitas tertinggi diperoleh perlakuan alkali dengan kadar $\mathrm{NaOH} 2,5 \mathrm{wt} \%$. Kuat tarik, regangan patah dan modulus elastisitas tertinggi, berturut-turut $203,02 \mathrm{MPa}, 3,733 \%$ dan $11,938 \mathrm{GPa}$, diperoleh dari lama waktu perendaman 3 jam.

\section{Daftar Pustaka}

[1] Campbell, F.C. Chapter 1. Introduction to Composite Materials, in Campbell, F.C.: Structural Composite Materials. Metals Park: ASM International: 1-30, 2010.

[2] Rajak, D.P., Pagar, D.D., Menezes, P.L., Linul, E., "Fiber-Reinforced Polymer Composites: Manufacturing, Properties, and Applications", Polymers, vol.11, no.10, pp 1167, 2019.

[3] Lebreton, L.C.M., van der Zwet, J., Damsteeg, J.W., Slat, B., Andrady, A., Reisser, J., "River Plastic Emissions to the World's Oceans, Nature Communications 8: 15611, 2017. 
[4] Pickering, K.L., Efendy, M.G.A., Le, T.M., "A review of recent developments in natural fibre composites and their mechanical performance", Composites: Part A 83: 98-112, 2016.

[5] Subyakto, Gopar, M., 2009, "Tinjauan Penelitian Terkini tentang Pemanfaatan Komposit Serat Alam untuk Komponen Otomotif", Journal of Tropical Wood Science \& Technology, vol. 7, no.2, pp 92-97, 2016.

[6] Fidelis, M.E.A., Pereira, T.V.C., Gomes, O.F.M., Silva, F.A., Filho, R.D.T., "The Effect of Fiber Morphology on the Tensile Strenght Natural Fibers", Journal of Materials Research and Technology, vol. 2, no.2, pp. 149-157, 2013.

[7] "ASTM D339, Standard Test Method for Tensile Strength and Young's Modulus for High-Modulus Single-Filament Materials" ASTM International, 100 Barr Harbor Drive, PO Box C700, West Conshohocken, PA, USA.

[8] National Institutes of Health (NIH), U.S. Department of Health.

[9] Gurunathan, T., Mohanty, S., Nayak, S.K., "Review of the Recent Developments in Biocomposites Based on Natural Fibres and Their Application Perspectives", Composites : Part A vol.77, no.4,pp. 1-25, 2015.

[10] Sosiati, H., Nahyudin, A., Wijayanti, D.A., Triyana, K., Sudarisman, "Effect of Alkali Treatment and MAPP Addition on Tensile Strength of Sisal/Polypropylene Composites", Journal of Advanced Manufacturing Technology, vol. 12, no.2, pp. 65-79, 2018.

[11] Peças, P., Carvalho, H., Salman, H., Leite, M., "Natural Fibre Composites and Their Applications, A Review", Journal of Composites Science, vol.2, no.4, pp. 66, 2018. 